\title{
Role of ecosystem components in Cd removal process of aquatic ecosystem
}

\author{
J. N. Bhakta and Y. Munekage ${ }^{\mathrm{b}}$
}

${ }^{\text {a} P a r a s i t o l o g y ~ L a b o r a t o r y, ~ D e p a r t m e n t ~ o f ~ Z o o l o g y, ~ U n i v e r s i t y ~ o f ~ K a l y a n i, ~ K a l y a n i ~-~ 741235, ~}$ West Bengal, India, E-mail: 1snjbhakta@rediffmail.com, Tel: +91 033 25821254, Fax: +91 03325828282

${ }^{b}$ Department of Environmental Engineering, Faculty of Agriculture, Kochi University. B200 Monobe, Nankoku, Kochi, Japan, E-mail: munekage@kochi-u.ac.jp, Tel \& Fax: +81-88-8645175

Corresponding Author: Fax: +91 033-2582 8282, E-mail: 1snjbhakta@rediffmail.com

\begin{abstract}
Experiment was conducted using fifteen glass aquariums to ascertain the pathways of removal of cadmium through numerical and compositional manipulation of ecosystem components and their role in Cd removal in different aquatic ecosystem. Each aquarium was provided with surface sediment @ $2 \mathrm{~kg}$, filled with $15 \mathrm{~L}$ tap water and randomly distributed into five treatments having three replicates in each. Cadmium chloride $\left(\mathrm{CdCl}_{2}\right)$ of analytical grade was added @ $2 \mathrm{mg} / \mathrm{L}$ to the water of each aquarium and mixed gently. Except first one, rest four systems received unio (Lamellidens marginalis, $55 \pm 2.5 \mathrm{~g}$ ) @ 6 pieces/aquarium. Tilapia (Oreochromis mossambicus, $35 \pm 3$ g) was introduced @ 6 fish/aquarium in third and fifth system, where as pistia (Pistia stratiotes) was introduced @ 50 g/aquarium in fourth and fifth system for 28 days observation period. The samples of water, sediment, unio, fish and pistia were collected from different system at every seven days intervals and analyzed. Results revealed that mean substantial reduction of $\mathrm{Cd}$ in water varied between 1.820 to $1.994 \mathrm{mg} / \mathrm{L}$ in
\end{abstract}


different simulated ecosystem. Ecosystem efficiency of $\mathrm{Cd}$ removal was varied in different ecosystems and showed highest $(11 \%)$ value in the ecosystem carrying five components that suggested a cumulative effect of increasing number of components employed in different simulated aquatic ecosystem significantly facilitated to reduce the level of $\mathrm{Cd}$ concentration in water column. Pistia exerted (10 - 204 times) higher rate of $\mathrm{Cd}$ accumulation over the other components employed in five simulated ecosystems of various component structures. Therefore, in the present study, it may be concluded that ecosystem carrying five components exhibited best performance for optimum minimization of $\mathrm{Cd}$ removal from water column. It can also be concluded that ecosystem components showed a variable performance and pistia was the efficient component in Cd removal point of view.

Key words: Cadmium, ecosystem, ecosystem component, cadmium removal efficiency.

\section{Introduction}

Cadmium is a 'priority pollutant', not only from the human health perspective, but also from a broader ecosystem viewpoint (Campbell, 2006). In general, it is a biologically non-essential, non-biodegradable, persistent type of heavy metal and its compounds are known to have high toxic potentials. There is increasing concern regarding the likely impact of cadmium in the environment, because it is a carcinogenic element posing risks to ecosystems and humans, and is hazardous in excessive amounts (SCOPE, 2000). Another important adverse property of cadmium is their ability of amply accumulating in the sediments and in the aquatic flora and fauna (by bioaccumulation and biomagnification) that causing a gross biological impact.

Industrial effluents and agricultural runoff containing toxic and hazardous substances including heavy metals discharge into water and tremendously contaminate the aquatic 
environment (Munger et al., 1999, Gbem et al., 2001 and Woodling et al., 2001). Cadmium emissions to water arise, in decreasing order of importance, from phosphate fertilizers, nonferrous metals production, and the iron and steel industry (OECD, 1994, ERL, 1990 and Van Assche and Ciarletta, 1992).

Sediments absorb heavy metals such as lead, zinc, copper, nickel, cadmium, chromium etc. from water and accumulate in its different tiers. The view is emerging in certain quarters that cadmium from phosphorus fertilizers poses a potentially serious threat to soil quality and, through the food chain, to human health (Oosterhuis et al., 2000).

Aquatic organisms take up heavy metals, concentrate them to amounts considerably higher than those found in the environment (Ferard et al., 1983) and exhibit toxicity effects (Witeska et al., 1995 and Pelgrom et al., 1994). Benthic communities take up heavy metals from environment and are generally characterized by reduced abundance, lower species diversity, and shifts in community composition from sensitive to tolerant taxa (Winner et al., 1980, La Point et al., 1984 and Clements, 1991). Jana and Das (1997) put forwarded that Lamellidens might be used as a biofilter for the reclamation of cadmium contaminated aquatic environment. Cadmium is also an important xenobiotic and cumulative pollutant in aquatic ecosystems and fish are particularly vulnerable to cadmium exposure (Sorensen, 1991). In fish, cadmium uptake is took place mainly through three routes namely, gills, skin and also from food via the intestinal wall and accumulated (Karlsson-Norrgran and Runn,1985; Edgren and Notter, 1989 and Kumada et al., 1980). On the other hand, the metal retention capacity of fish is dependent on the metal assimilation and excretion capacities of the fish concerned (Rao and Patnaik, 1999). Aquatic plants uptake the substances from contaminated aquatic environment via surface of the roots and leaves (i.e., phytoremediation), which helps in cleaning up heavy metals, pesticides and 
xenobiotics (Suresh and Ravishankar, 2004), organic compounds (Newman and Reynolds, 2004), toxic aromatic pollutants (Singh and Jain, 2003) and acid mine drainage (Archer and Caldwell, 2004).

Cadmium uptake by these above discussed ecosystem components is a significant aspect in ecosystem based reclamation of aquatic environment which is presently being eco-friendly recognized approach. Understanding of the efficiency of different ecosystem based managed models of various numerical and compositional structure of components to remove heavy metal from the aqueous phase is important in the present hazardous heavy metal polluted aquatic environment. There is scanty of information regarding the role of different ecosystem components under various ecosystems to minimize the heavy metal toxicants in aqueous medium. Development of such promising ecosystem model depending on various numerical and compositional structures of components would play a significant role to provide a heavy metal like toxic elementless aquatic environment. Therefore, the present study has been focused to ascertain the pathways of removal of cadmium through numerical and compositional manipulation of ecosystem components and their role in $\mathrm{Cd}$ removal in different aquatic ecosystem.

\section{Materials and Methods}

Study used fifteen glass aquariums (20 L), were provided with surface sediment (Silt 20\%, mud/clay $75 \%$, sand $5 \%$ and $\mathrm{pH} 7.4$ ) at the bottom which was collected from four different sites of a local pond using a suitable hand grab sampler, mixed to create homogenous one, dispensed at the rate of $2 \mathrm{~kg} /$ aquarium and filled with $15 \mathrm{~L}$ tap water (pH 7.6 and temperature 28.5). All the aquariums were randomly distributed into five treatments of three replicates (each treatment 
herein called as ecosystem i.e, $\mathrm{ES}_{1}-\mathrm{ES}_{5}$ ). Cadmium chloride [ $\mathrm{CdCl}_{2}$, E. Merck (India) Ltd.] of analytical grade was collected from market and added @ 2mg/L to water of each aquarium and mixed gently.

Unio (Lamellidens marginalis, $55 \pm 2.5 \mathrm{~g}$ ), tilapia (Oreochromis mossambicus, $35 \pm 3 \mathrm{~g}$ ) and pistia (Pistia stratiotes) were procured from a local fish pond, acclimatized for a week and employed as benthic organism, water column habitant and aquatic plant in simulated experimental system, respectively. Except $\mathrm{ES}_{1}$, rest four systems received unio @6 pieces/aquarium and tilapia introduced @ 6 fish/aquarium in $\mathrm{ES}_{3}$ and $\mathrm{ES}_{5}$ where as pistia introduced @ 50 g/aquarium in $\mathrm{ES}_{4}$ and $\mathrm{ES}_{5}$ for 28 days observation period. Loss of water due to sampling was compensated by adding the equal volume of same water. Designed five simulated ecosystems have been shown in figure 1.

The samples of water $(100 \mathrm{~mL})$, sediment (25 gm), unio (one), fish (one) and pistia (8 gm) were collected from different aquarium at a fixed hour $(9.00 \mathrm{am})$ at every seven days intervals using a suitable small hand made specific samplers for different types of samples. Water and sediment samples were collected from four sites of each aquarium and then pooled into one for each aquarium before final analysis. For analysis of the cadmium (Cd) $100 \mathrm{~mL}$ water samples were digested with $2 \mathrm{~mL}$ nitric acid in Kjeldahl flask. Sediment and whole organisms of unio, fish and plant samples of each aquarium were dried overnight at $100^{\circ} \mathrm{C}$, make a fine powder and sieved the powder of whole organism through a $63 \mu \mathrm{m}$ mesh to get equal size of particles smaller than $63 \mu \mathrm{m}$ (Fenchel et al., 1975) for easy digestion. Twenty $\mathrm{mL}$ of concentrated nitric acid was added to $1 \mathrm{~g}$ of each of the dried powder samples in Kjeldahl flask and were digested within a digestion chamber at $80^{\circ} \mathrm{C}$ (Bat and Raffaelli, 1999). After digestion the resultant solutions were allowed to cool and the residue was diluted with double-distilled water to $50 \mathrm{~mL}$ and measured 
by using flame atomic absorption spectrometry (VARIAN, AA 240). The concentration of Cd was calculated in terms of per $\mathrm{ml}$ for water and per gram dry weight for sediment, unio, fish and pistia.

Cd removal efficiency of ecosystem (i.e, Ecosystem efficiency) was determined calculating the reduction of $\mathrm{Cd}$ concentration in water using the following formula:

$$
\mathrm{EE}=\frac{\mathrm{Cd}_{\mathrm{i}}-\mathrm{Cd}_{\mathrm{f}}}{\mathrm{Cd}_{\mathrm{i}}} \times 100
$$

Where, $\mathrm{EE}=$ Ecosystem efficiency

$\mathrm{Cd}_{\mathrm{i}}=$ Initial concentration of $\mathrm{Cd}$ in water (after application of $\mathrm{CdCl}_{2}$ )

$\mathrm{Cd}_{\mathrm{f}}=$ Final concentration of $\mathrm{Cd}$ in water

The rate of accumulation of $\mathrm{Cd}$ by employed different components of ecosystem was estimated as component efficiency. The component efficiency was written as $\alpha$. $\delta$ is designated for $\mathrm{Cd}$ content in components, then initial and final content were represented as $\delta_{\mathrm{i}}$ and $\delta_{\mathrm{f}}$, respectively. $t$ was depicted as time, then final and initial time represented as $t_{f}$ and $t_{i}$, respectively. The component efficiency in respect to $\mathrm{Cd}$ accumulation can also be expressed by the following formula:

$$
\alpha=\frac{\delta_{\mathrm{f}}-\delta_{\mathrm{i}}}{\mathrm{t}_{\mathrm{f}}-\mathrm{t}_{\mathrm{i}}}
$$

All results obtained from the aquariums were statistically interpreted. A one way ANOVA (Gomez and Gomez, 1984) was used to compare the treatment means. Before analysis, the assumptions of normal distributions and homogeneity of the variance were checked using 
Kolmogrov-Smirnov and Cochran's tests, respectively. If the main effect was found to be significant, the ANOVA was followed by a LSD (least significance difference) test. All statistical tests were performed at 5\% probability level using statistical package EASE and MSTAT.

\section{Results}

\subsection{Cd in water}

Concentration of $\mathrm{Cd}$ in water ranged from $0.001-2.0 \mathrm{mg} / \mathrm{L}$. There was a significant system difference (ANOVA; $\mathrm{P}<0.05)$ in mean final values of $\mathrm{Cd}$ showing the trend of variation as follows: $\mathrm{ES}_{1}>\mathrm{ES}_{2}>\mathrm{ES}_{3}>\mathrm{ES}_{4}>\mathrm{ES}_{5}$. The highest mean final value $(0.180 \mathrm{mg} / \mathrm{L})$ of $\mathrm{ES}_{1}$ was 2.16, 3.24, 6.38 and 30 times higher than that of the $\mathrm{ES}_{2}, \mathrm{ES}_{3}, \mathrm{ES}_{4}$ and $\mathrm{ES}_{5}$, respectively (Table 1). Temporal course of variation in the Cd concentration showed a gradual declining trend in all system (Fig. 2). The decreasing rate was maximum in $\mathrm{ES}_{5}$ and minimum in $\mathrm{ES}_{1}$.

\subsection{Cd in sediment}

The Cd content of sediment varied $(0.002-0.0176 \mathrm{mg} / \mathrm{g})$ significantly (ANOVA; $\mathrm{P}<0.05)$ in all the systems employed. The mean final value was maximum $(0.0175 \mathrm{mg} / \mathrm{g})$ in the $\mathrm{ES}_{1}$ exhibiting the following order of variations: $\mathrm{ES}_{1}>\mathrm{ES}_{2}>\mathrm{ES}_{3}>\mathrm{ES}_{4}>\mathrm{ES}_{5}$ (Table 1). The concentration of $\mathrm{Cd}$ in $\mathrm{ES}_{1}$ was 12, 36, 186 and $326 \%$ higher compare to that of $\mathrm{ES}_{2}, \mathrm{ES}_{3}, \mathrm{ES}_{4}$ and $\mathrm{ES}_{5}$, respectively. The Cd concentration of soil gradually increased (105 to 340\%) with time (Fig. 2). 


\subsection{Cd in unio (Lamellidens marginalis)}

The accumulated $\mathrm{Cd}$ in unio varied between 0.004 and $0.079 \mathrm{mg} / \mathrm{g}$ in different systems. The maximum final concentration of $\mathrm{Cd}(0.079 \mathrm{mg} / \mathrm{g})$ in $\mathrm{ES}_{2}$ revealed 18,49 and $53 \%$ higher value than that of $\mathrm{ES}_{3}, \mathrm{ES}_{4}$ and $\mathrm{ES}_{5}$, respectively (Table 1). Temporally the concentration of $\mathrm{Cd}$ exhibited an increasing trend over time that ranged from 1220 to $1600 \%$ in all systems (Fig. 2).

\subsection{Cd in tilapia (Oreochromis mossambicus)}

The concentration of $\mathrm{Cd}$ in fish tissue of $\mathrm{ES}_{3}$ and $\mathrm{ES}_{5}$ ranged from $0.002-0.0076 \mathrm{mg} / \mathrm{g}$. There was a significant difference (ANOVA; $\mathrm{P}<0.05)$ in the mean final content of Cd in two systems and registered $130 \%$ higher value in $\mathrm{ES}_{3}$ than that of the $\mathrm{ES}_{5}$ (Table 1). Time course variation was also similar as that of the Unio (Fig. 2).

\subsection{Cd in pistia (Pistia stratiotes)}

Cd content of plant tissue ranged from 0.005 to $0.725 \mathrm{mg} / \mathrm{g}$ in $\mathrm{ES}_{4}$ and $\mathrm{ES}_{5}$. The mean final Cd content $(0.724 \mathrm{mg} / \mathrm{g})$ in $\mathrm{ES}_{4}$ pronounced 1.17 times elevated value compared to that of the $\mathrm{ES}_{5}$. As time progressed, both $\mathrm{ES}_{4}$ and $\mathrm{ES}_{5}$ system revealed a sharp increasing trend (Fig. 2).

\subsection{Cd removal efficiency}

Ecosystem efficiency varied from 90 to $99.5 \%$ and showing increasing trend with increasing number of ecosystem components (Fig. 4). Component efficiency (i.e, rate of $\mathrm{Cd}$ accumulation) also ranged from 0.075 to $0.44 \times 10^{-3} \mathrm{mg} / \mathrm{g} / \mathrm{d}, 1.7$ to $2.6 \times 10^{-3} \mathrm{mg} / \mathrm{g} / \mathrm{d}, 0.04$ to $0.198 \times 10^{-3}$ $\mathrm{mg} / \mathrm{g} / \mathrm{d}$ and 21.9 to $25.5 \times 10^{-3} \mathrm{mg} / \mathrm{g} / \mathrm{d}$ in sediment, unio, tilapia and pistia, respectively in 
different ecosystem (Fig. 3). Unlike ecosystem efficiency, component efficiency showed a reverse response with the increasing number of ecosystem components.

\section{Discussions}

Final Cd concentrations of water pronounced by $0.18,0.083,0.055,0.028$ and $0.006 \mathrm{mg} / \mathrm{L}$ from the highest concentration $2 \mathrm{mg} / \mathrm{L}$ (just after application of $\mathrm{Cd}$ ) in $\mathrm{ES}_{1}, \mathrm{ES}_{2}, \mathrm{ES}_{3}, \mathrm{ES}_{4}$ and $\mathrm{ES}_{5}$, respectively. Results obtained from the study also demonstrated that mean substantial reduction of Cd varied between 1.820 to $1.994 \mathrm{mg} / \mathrm{L}$ in different simulated ecosystem (Fig. 3). Above resultant data clearly revealed a system dependent sharp reduction of $\mathrm{Cd}$ was by means of differential functional efficiency factors of ecosystem and its components.

\subsection{Ecosystem efficiency}

Systems efficiencies of Cd removal were $5 \%, 8 \%, 9 \%$ and $11 \%$ higher in $\mathrm{ES}_{2}, \mathrm{ES}_{3}, \mathrm{ES}_{4}$ and $\mathrm{ES}_{5}$, respectively than that of the $\mathrm{ES}_{1}$ which suggested a cumulative effect of increasing number of components employed in different simulated aquatic ecosystem significantly facilitated the process of $\mathrm{Cd}$ concentration reduction in water column. Relationship between the ecosystem efficiency (SE) of Cd removal and number of ecosystem component employed showed that ecosystem efficiency was improved with increasing number of component which also strongly implying a synergistic effect of all ecosystem components has a high potential Cd withdrawn mechanism from water column in $\mathrm{ES}_{5}$ (Fig. 4). However, it is of fundamental importance to the longer term availability and sustainable management of water resources that the maintenance of ecosystems and the strengthening of their role as providers of services and goods is recognized (Laanbrock et al., 1996). 


\subsection{Component efficiency in different systems}

Sediment of $\mathrm{ES}_{1}$ showed $15-486 \%$ higher absorption efficiency than that of the remaining four systems. Out of four systems $\left(\mathrm{ES}_{2}, \mathrm{ES}_{3}, \mathrm{ES}_{4}\right.$ and $\left.\mathrm{ES}_{5}\right), \mathrm{Cd}$ accumulation efficiency of unio was maximum (0.26\%) in $\mathrm{ES}_{2}$ system. Tilapia of $\mathrm{ES}_{3}$ exhibited 5 times higher accumulation of $\mathrm{Cd}$ compared to $\mathrm{ES}_{5}$, whereas pistia in $\mathrm{ES}_{4}$ pronounced 1.2 times elevated value of $\mathrm{Cd}$ accumulation efficiency compared to that of the $\mathrm{ES}_{5}$. Above data strongly implied that each component might have a differential performance in $\mathrm{Cd}$ accumulation in different simulated ecosystem (Fig. 3). A reverse relationship was also found between the Cd removal component efficiency (CE) and number of ecosystem component which also clearly demonstrated that component efficiency decreased with increased number of ecosystem component (Fig. 2). Individual and population patterns of bioaccumulation were analyzed by comparing the simulated results of five different scenarios of dissolved metal concentrations (Simas et al., 2001).

\subsection{Component efficiency within the systems}

In $\mathrm{ES}_{1}$, sediment showed $340 \%$ absorption, whereas maximum efficiency of $\mathrm{Cd}$ accumulation in unio was $4-5.1$ and $4-4.6$ times higher in $\mathrm{ES}_{2}$ and $\mathrm{ES}_{3}$, respectively and pistia exerted $11-204$ and $10-119$ times highest potential of $\mathrm{Cd}$ accumulation in $\mathrm{ES}_{4}$ and $\mathrm{ES}_{5}$, respectively among the other components employed in five respected simulated ecosystems with various combinations of components. It therefore, may be concluded considering the above results; ecosystem components showed a variable performance and pistia was efficient component in $\mathrm{Cd}$ uptake point of view (Fig. 3). It was studied that the aquatic plants are 
responsible for fast metal abatement from aquatic environment (Rai et al., 1995 and Das and Jana, 1999) and the arsenate removal efficiency of pistia (Pistia stratiotes L.) is maximum (87.5\%) at pH 6.5 (Mukherjee and Kumar, 2005).

\section{Conclusion}

On account of the above discussion, it may be concluded that though, $\mathrm{Cd}$ accumulation by the sediment plays an important role to decrease the Cd level of water in $\mathrm{ES}_{1}$ system in one hand, whereas, Cd uptake and finally differential accumulation in the tissue of aquatic organism was the potential factors for declining the Cd concentration of water in remaining systems $\left(\mathrm{ES}_{2}-\right.$ $\mathrm{ES}_{5}$ ) on the other hand, but their efficiency of accumulation varied with respect to different systems carrying various composition of components. Transport of metals into the intracellular section aided by either diffusion of the metal ion across the cell membrane or by active transport by a carrier protein (Brezonik et al., 1991 and Wepener et al., 2001). Moreover, in this connection, it was obvious that ecosystem components serve as a physical and biological buffer to minimize the heavy metal load in water column. Coastal wetlands ecosystems, such as salt marshes and mangroves, also function as buffers and regulators of water quality (Koch et al., 1992).

In the present study, overall explanation of the results affords to draw a conclusion that - (1) The Cd removal from water column of an ecosystem largely depends on performance/efficiency of the ecosystem which is improved my numerical manipulation - i.e., increase the number of ecosystem components and compositional manipulation - i.e., selective employment of ecosystem components of different trophic level. (2) Individual component efficiency was increased when single trophic component were employed and decreased when the different 
trohic components are present in an ecosystem. (3) Among the employed different components the component efficiency of pistia pronounced its best performance and contributed maximum part to remove the Cd from water column in an ecosystem. According to De Groot (1992), Ecosystem functions are defined as the capacity of natural processes and components of natural or semi-natural systems to provide services and goods that satisfy human needs (directly or indirectly). Finally, it may be proposed from the study that 'manipulating numerical and compositional structure of components-related ecosystem' is an efficient model of ecosystem to remove as well as to over come the toxicity problems of $\mathrm{Cd}$, other heavy metals and various nutrients in the aquatic environment.

\section{Acknowledgement}

We are thankful to Prof. P. K. Bandyopadhyay who extended his kind cooperation providing laboratory facilities and also grateful for his valuable contribution to the research work

\section{References}

Archer, M.J.G. and R.A. Caldwell, 2004. Response of six Australian plant species to heavy metal contamination at an abandoned mine site. Water Air Soil Poll., 157:257-267.

Bat, L. and D. Raffaelli, 1999. Effects of Gut Sediment Contents on Heavy Metal Levels in the Amphipod Corophium volutator (Pallas). Tr. J. of Zoology, 23:67-71

Brezonik, P.L., S.O. King, and C.E. Mach, 1991. The influence of water chemistry on trace metal bioavailability and toxicity to aquatic organisms. In: M.C. Newman and A.W. McIntosh (Eds), Metal ecotoxicology, concepts and applications, Lewis Publishers, Michigan, 399 pp. 
Campbell, P.G.C., 2006. Cadmium - A Priority Pollutant. Environ. Chem., 3:387-388.

Clements, W.H., 1991. Community responses of stream organisms to heavy metals: A review of descriptive and experimental approaches. In: M.C. Newman, A.W. McIntosh and FL Boca Raton (Eds), Ecotoxicology of Metals: Current Concepts and Applications, CRC Press, pp 363-391.

Das, S. and B.B. Jana, 1999. Dose-dependent uptake and Eichhornia-induced elimination of cadmium in various organs of the freshwater mussel, Lamellidens marginalis (Linn.). Ecological Engineering, 12(3-4):207-229.

De Groot, R.S., 1992. Fuctions of nature. Evaluation of nature in environmental planning, management and decision making. Wolters Noordhoff, Deventer, The Netherlands, 315 pp.

Edgren, M. and M. Notter, 1989. Cadmium uptake by fingerlings of perch (Perca fluviatilis) studied by $\mathrm{Cd}-115 \mathrm{~m}$ at two different temperatures. Bull. Environ. Contamin. Toxicol., 24:647.

ERL (Environmental Resources Limited), 1990. Evaluation of the Sources of Human and Environmental Contamination by Cadmium. Prepared for the Commission of the European Community, Directorate General for Environment, Consumer Protection and Nuclear Safety, London.

Fenchel, T., L.H. Kofoed and A. Lappalainen, 1975. Particle sizeselection of two deposit feeders: the Amphipod Corophium volutator and the Prosobranch Hydrobia ulvae, Mar. Biol., 30:119-128.

Ferard, J.F., J.M. Jouany, R. Truhaut and P. Vasseur, 1983. Accumulation of cadmium in a freshwater food chain experimental model. Ecotoxicol. Environ. Safe., 7: 43-52. 
Gbem, T.T., J.K. Balogun, F.A. Lawal and P.A. Annune, 2001. Trace metal accumulation in Clarias gariepinus Teugules exposed to sublethal levels of tannery effluent. Sci. Total. Environ., 271:1-9.

Gomez, K.A. and A.A. Gomez, 1984. Statistical Procedures for Agricultural Research. $2^{\text {nd }}$ edn. John Wiley and Sons, New York, 680pp.

Jana, B.B. and S. Das, 1997. Potential of freshwater mussel (Lamellidens marginalis) for cadmium clearance in a model system. Ecological Engineering, 8(3):179-193.

Karlsson-Norrgren, L. and P. Runn, 1985. Cadmium dynamics in fish: Pulse studies with ${ }^{109} \mathrm{Cd}$ in female Zebrafish, Brachydanio rerio. J. Fish. Biol., 27: 571-581.

Koch, M.S., E. Maltby, G.A. Oliver and S.A. Bakker, 1992. Factors controlling denitrification dates of tidal mudflats and fringing salt marshes in south-west England. Estuarine, Coastal and Shelf Science, 34:471-485.

Kumada, H., S. Kimura and M. Vokote, 1980. Accumulation and biological effects of cadmium in rainbow trout. Bull. Jap. Soc. Scient. Fish., 46(1): 97.

La Point, T.W. S.M. Melancan and M.I. Morris, 1984. Relationships, Among Observed Metal Concentrations, Criteria, and Benthic Community Structural Responses in 15 Streams. Journal of the Water Pollution Control Federation, 56:1030-1038.

Laanbroek, H.J., E. Maltby, P. Whitehead, B. Faafeng, and H. Barth, 1996. Wetland and aquatic ecosystem research science plan. European Commission, Brussels, Belgium, pp. 26-27.

Munger, C., L. Hare, A. Craig and P.M. Charest, 1999. Influence of exposure time on the distribution of cadmium within the cladoceran Ceriodaphnia dubia. Aquatic Toxicology, 44:195-200. 
Newman, L.A. and C.M. Reynolds, 2004. Phytodegradation of organic compounds. Curr. Opin. Biotech., 15:225-230.

OECD, 1996. Capacity development in environment. Proceedings of the IIED/OECD workshop, $301 \mathrm{pp}$.

Oosterhuis, F.H., F.M. Brouwer and H.J. Wijnants, 2000. A possible EU wide charge on cadmium in phosphate fertilisers: Economic and environmental implications. Final Report to the EU Commission. Report Number E-00/02. Institute for Environmental Studies, Vrije Universiteit, Amsterdam, The Netherlands.

Pelgrom, S.M.G.J., L.P.M. Lamers, J.A.M Garritsen, B.M., Pels, R.A.C. Lock, P.H.M. Balm and S.E. Wendelaar Bonga, 1994. Interactions between copper and cadmium during single and combined exposure in juvenile tilapia Oreochromis mossambicus: Influence of feeding condition on whole body metal accumulation and the effect of the metals on tissue water and ion content. Aquatic Toxicology., 30:117-135.

Rai, U.N., S. Sinha, R.D. Tripathi and P. Chandra, 1995. Wastewater treatability potential of some aquatic macrophytes: Removal of heavy metals. Ecological Engineering, 5(1):5 -12.

Rao, L.M. and R. Patnaik, 1999. Heavy metal accumulation in the catfish Mystus vittatus (Bloch.) from Mehadrigedda stream of Visakhapatinam, India. Poll. Res., 19:325-329.

S. Mukherjee and S. Kumar, 2005. Arsenic uptake potential of water lettuce (Pistia Stratiotes L.). International Journal of Environmental Studies, 62(2):249 - 258.

SCOPE, 2000. Report from the SCOPE Workshop on Environmental Cadmium in the Food Chain: Sources, Pathways and Risks. http:/www.icsu-scope.org.

Simas, T.C., A.P. Ribeiro, J.G. Ferreira, 2001. Shrimp - a dynamic model of heavy-metal uptake in aquatic macrofauna. Environmental Toxicology and Chemistry, 20(11): 2649-2656. 
Singh, O.V., R.K. Jain, 2003. Phytoremediation of toxic aromatic pollutants from soil. Appl. Microbiol. Biotech., 63:128-135.

Sorensen, E.M.B., 1991. Metal poisoning in fish. CRC Press, Boca Ration, Florida.

Suresh, B. and G.A. Ravishankar, 2004. Phytoremediation - A novel and promising approach for environmental clean-up. Crit. Rev. Biotechnol., 24:97-124.

Van Assche, F.J. and P. Ciarletta, 1992. "Cadmium in the Environment: Levels, Trends and Critical Pathways, Edited Proceedings Seventh International Cadmium Conference - New Orleans, Cadmium Association, London, Cadmium Council, Reston VA, International Lead Zinc Research Organisation, Research Triangle Park NC.

Wepener, V., J.H.J. Van Vuren and H.H. Du Preez, 2001. Uptake and distribution of a copper, iron and zinc mixture in gill, liver and plasma of a freshwater teleost, Tilapia sparmanii. Water SA. 27(1):99-108.

Winner, R.W., B.W. Boesel and M. P. Farrel, 1980. Insect Community Structure as an Index of Heavy-Metal Pollution in Lotic Ecosystems. Canadian Journal of Fisheries and Aquatic Science 37:647-655.

Witeska, M., B. Jezierska and J. Chaber, 1995. The influence of cadmium on common carp embryos and larvae. Aquaculture, 129:129-132.

Woodling, J.D., S.F. Brinkman and B.J. Horn, 2001. Non uniform accumulation of cadmium and copper in kidney's of wild brown trout Salmo trutta populations. Arch. Environ. Contam. Toxicol., 40:381-385. 
Table 1. Mean final values ( \pm S.E.) of $\mathrm{Cd}$ in different components under different simulated ecosystems employed. Same script among systems (rows) revealed lack of significant difference.

\begin{tabular}{|c|c|c|c|c|c|}
\hline \multirow[t]{2}{*}{ Components } & \multicolumn{5}{|c|}{ Ecosystem Systems } \\
\hline & $\mathbf{E S}_{1}$ & $\mathbf{E S}_{2}$ & $\mathbf{E S}_{\mathbf{3}}$ & $\mathbf{E S}_{4}$ & $\mathbf{E S}_{5}$ \\
\hline Water $(\mathrm{mg} / \mathrm{L})$ & $\begin{array}{c}0.180^{\mathrm{A}} \\
\pm 0.032\end{array}$ & $\begin{array}{l}0.083^{\mathrm{B}} \\
\pm 0.03\end{array}$ & $\begin{array}{c}0.0554^{\mathrm{C}} \\
\pm 0.03\end{array}$ & $\begin{array}{l}0.0282^{\mathrm{D}} \\
\pm 0.008\end{array}$ & $\begin{array}{c}0.006^{\mathrm{E}} \\
\pm 0.002\end{array}$ \\
\hline Soil (mg/g) & $\begin{array}{l}0.0175^{\mathrm{A}} \\
\pm 0.004\end{array}$ & $\begin{array}{c}0.0158^{\mathrm{B}} \\
\pm 0.0034\end{array}$ & $\begin{array}{c}0.0129^{\mathrm{C}} \\
\pm 0.0033\end{array}$ & $\begin{array}{l}0.0061^{\mathrm{D}} \\
\pm 0.001\end{array}$ & $\begin{array}{c}0.0041^{\mathrm{E}} \\
\pm 0.0005\end{array}$ \\
\hline Unio (mg/g) & - & $\begin{array}{l}0.079^{\mathrm{A}} \\
\pm 0.01\end{array}$ & $\begin{array}{c}0.067^{\mathrm{B}} \\
\pm 0.015\end{array}$ & $\begin{array}{c}0.053^{\mathrm{C}} \\
\pm 0.011\end{array}$ & $\begin{array}{l}0.0518^{C} \\
\pm 0.009\end{array}$ \\
\hline Tilapia (mg/g) & - & - & $\begin{array}{c}0.0076^{\mathrm{A}} \\
\pm 0.0008\end{array}$ & - & $\begin{array}{c}0.0033^{\mathrm{B}} \\
\pm 0.00071\end{array}$ \\
\hline Pistia (mg/g) & - & - & - & $\begin{array}{l}0.724^{\mathrm{A}} \\
\pm 0.05\end{array}$ & $\begin{array}{l}0.691^{\mathrm{B}} \\
\pm 0.04\end{array}$ \\
\hline
\end{tabular}




\section{Legends to figures}

Fig. 1. Experimental design showing the five different simulated aquatic ecosystems used.

Fig. 2. Temporal responses of $\mathrm{Cd}$ content in water and $\mathrm{Cd}$ uptake by ecosystem components in different simulated ecosystems. Arrow $(\longrightarrow$ ) indicatig the time of addition of $\mathrm{Cd}$ in water.

Fig. 3. Component efficiency (i.e, rate of Cd uptake) criteria of different components in five ecosystems during the period of experimentation. Inset showing decreasing of $\mathrm{Cd}$ concentration in water column with increasing number of components. Same script in the same component bars of different systems revealed lack of significant difference.

Fig. 4. Relationship between the ecosystem efficiency and number of ecosystem component. 


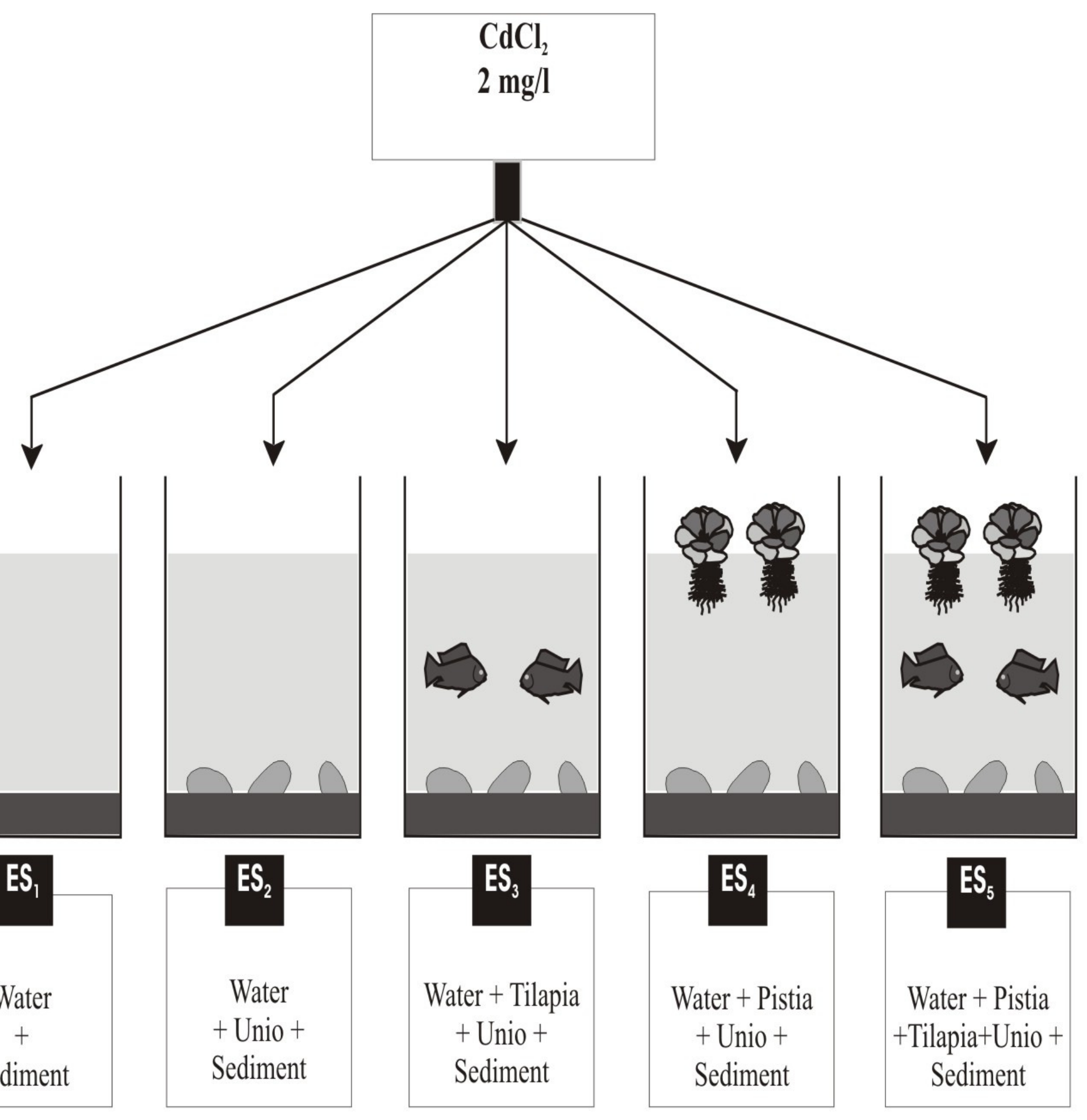

Figure 1. Experimental design showing the five different simulated aquatic ecosystems used 
$\mathrm{ES}_{1}$

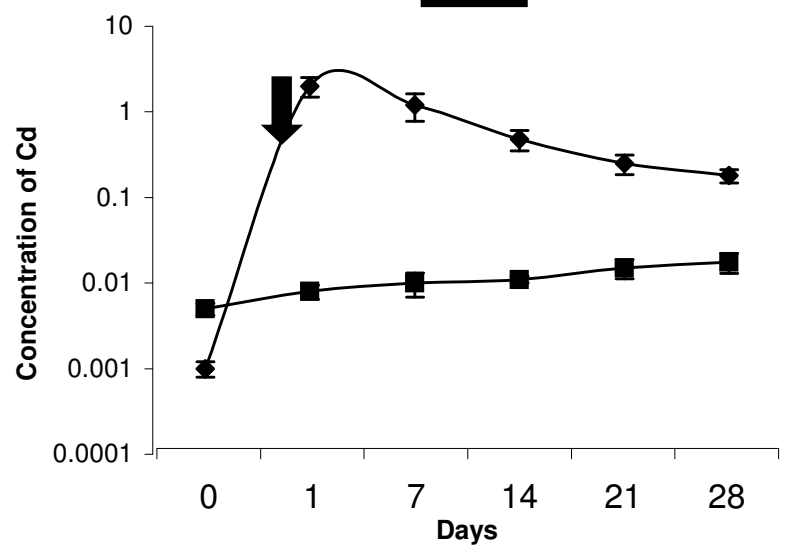

$\mathrm{ES}_{3}$

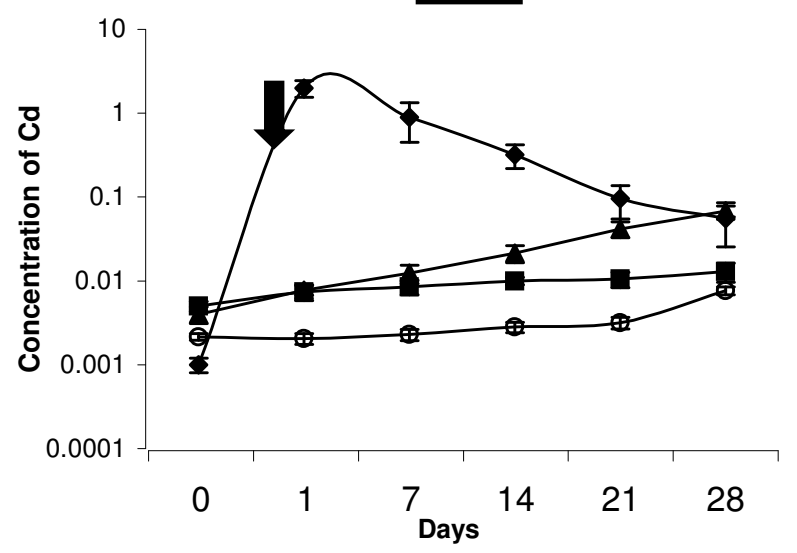

$\mathrm{ES}_{5}$

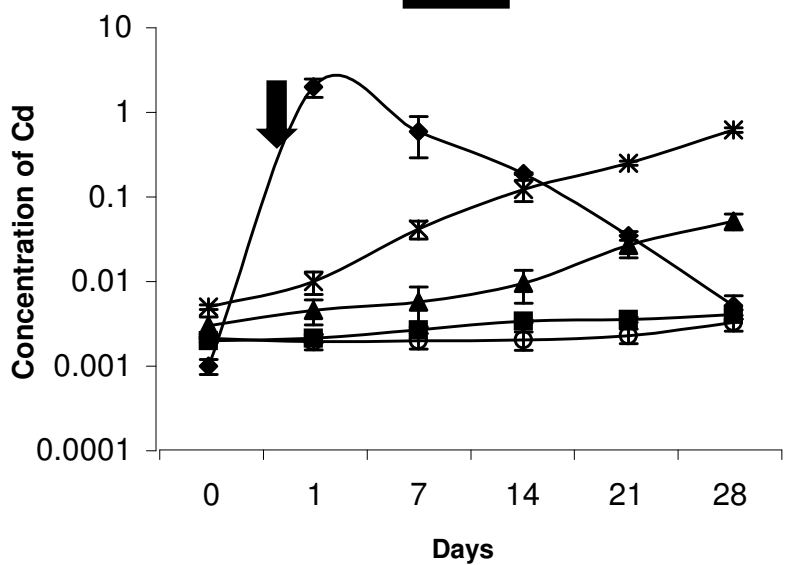

$\mathrm{ES}_{2}$

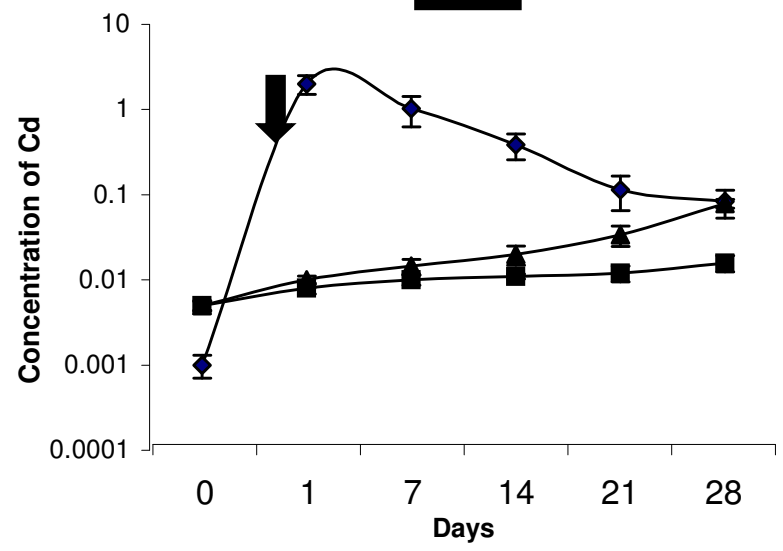

$\mathrm{ES}_{4}$

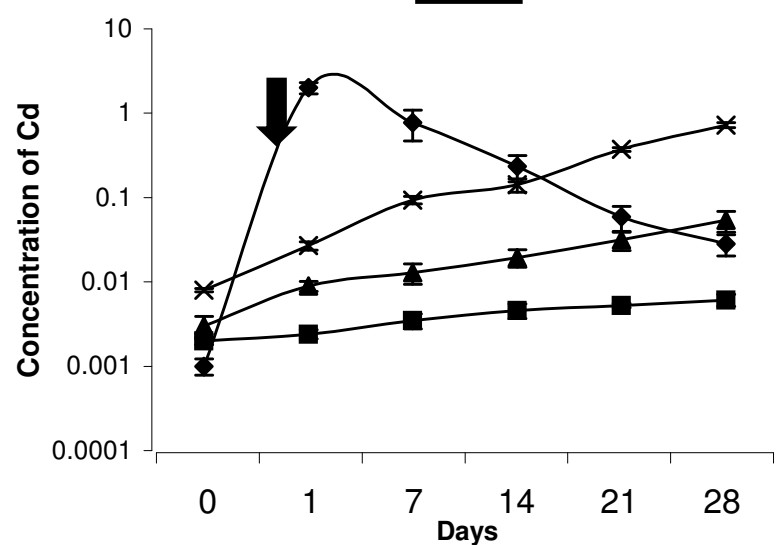

Fig. 2.

Temporal responses of $\mathrm{Cd}$ content in water and $\mathrm{Cd}$ uptake by ecosystem components in different simulated ecosystems. Arrow $(\longrightarrow$ ) indicatig the time of addition of Cadmium in 



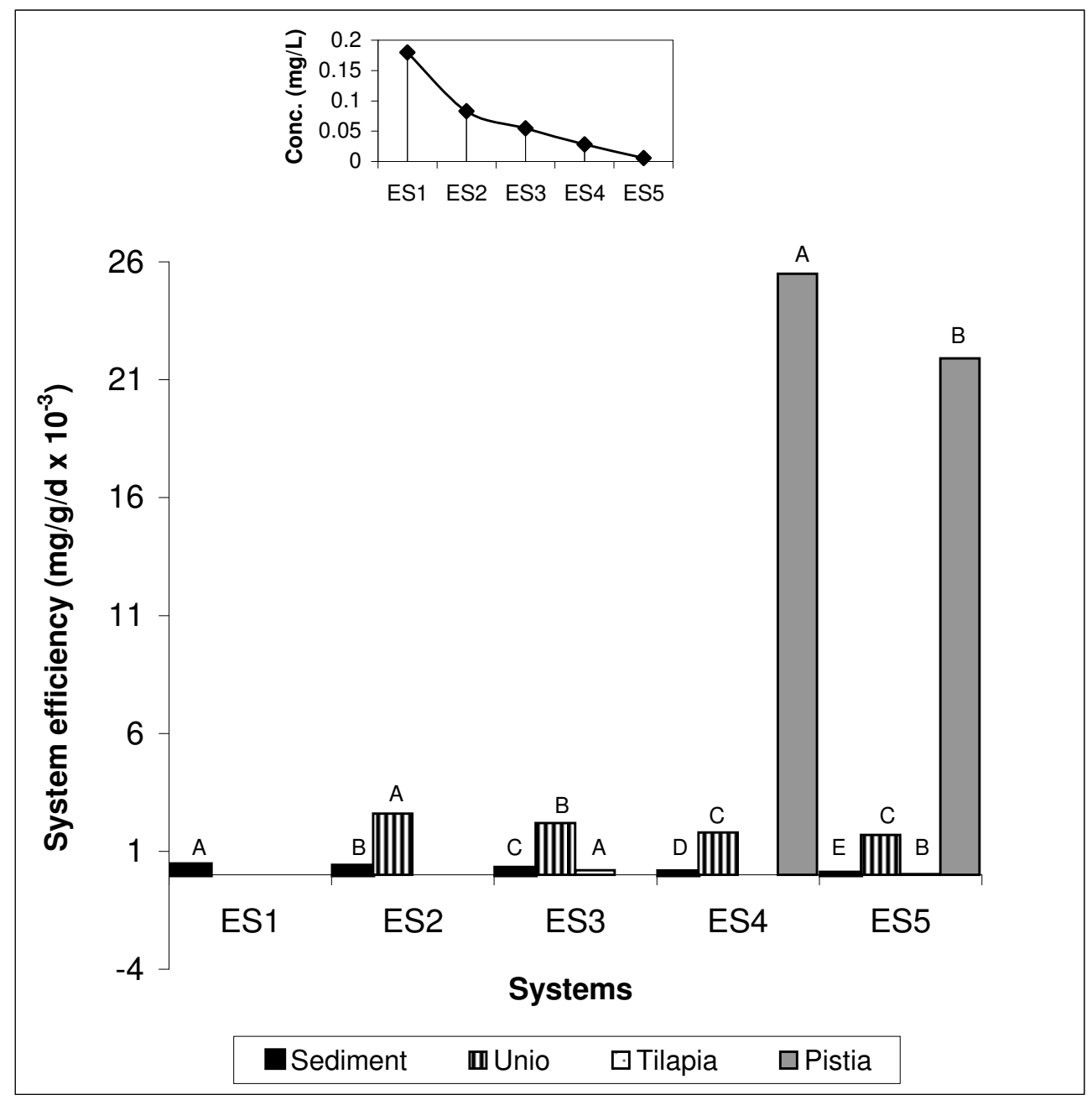

Fig. 3.

Component efficiency (i.e, rate of Cd uptake) criteria of different components in five ecosystems during the period of experimentation. Inset showing decreasing of $\mathrm{Cd}$ concentration in water column with increasing number of components. Same script in the same component bars of different systems revealed lack of significant difference. 


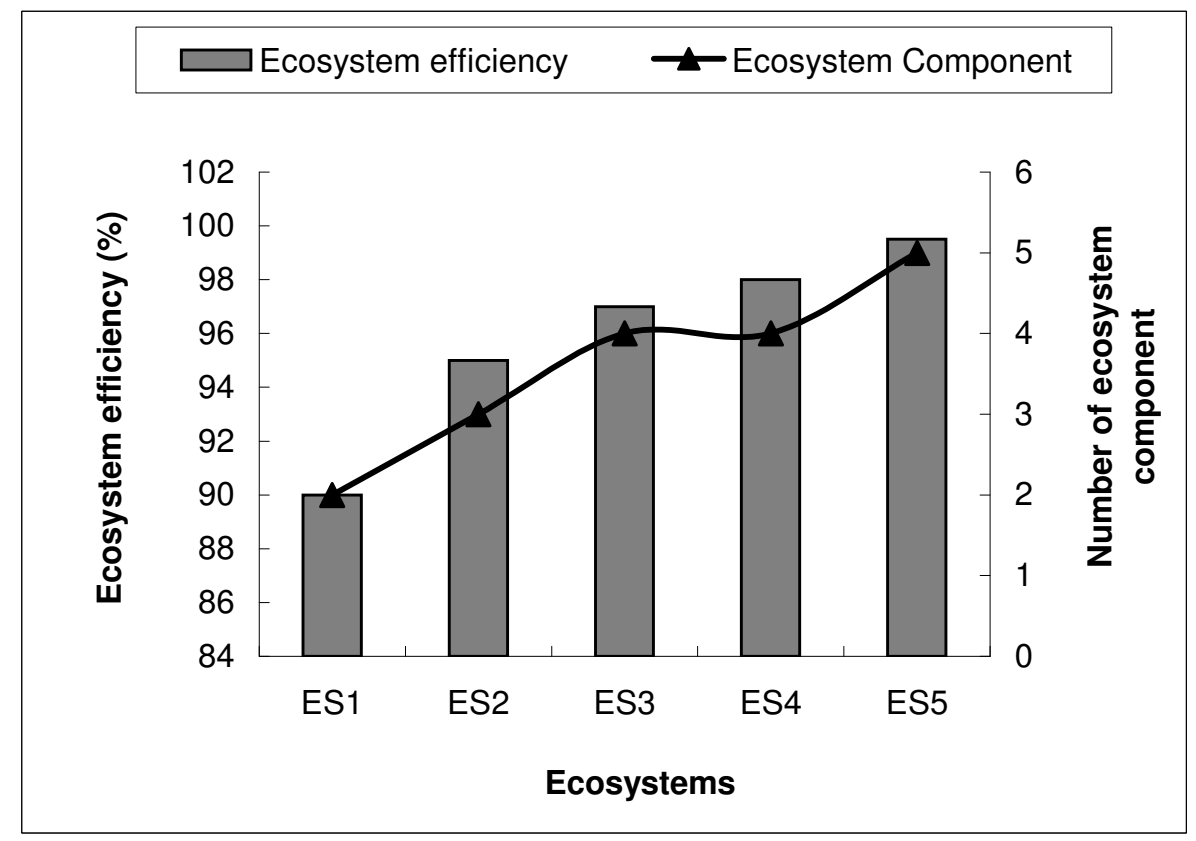

Fig. 4.

Relationship between the ecosystem efficiency and number of ecosystem component. 